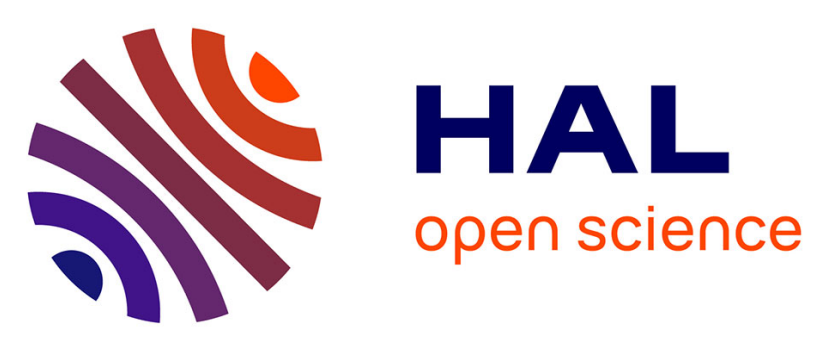

\title{
Karst-River Interaction, Elaboration of an Indicator of the Karst Hydrological Conditions Applied to the Cèze River (Gard, France)
}

Hervé Chapuis, Jordan Ré-Bahuaud, Joël Jolivet, Frédéric Paran, Didier Graillot

\section{To cite this version:}

Hervé Chapuis, Jordan Ré-Bahuaud, Joël Jolivet, Frédéric Paran, Didier Graillot. Karst-River Interaction, Elaboration of an Indicator of the Karst Hydrological Conditions Applied to the Cèze River (Gard, France). Eurokarst 2018, Universitéy de Franche-Comté; University of Neuchâtel, Jul 2018, Besançon, France. pp.77 à 81, 10.1007/978-3-030-14015-1_9 . emse-02378649

\section{HAL Id: emse-02378649 \\ https://hal-emse.ccsd.cnrs.fr/emse-02378649}

Submitted on 23 Mar 2020

HAL is a multi-disciplinary open access archive for the deposit and dissemination of scientific research documents, whether they are published or not. The documents may come from teaching and research institutions in France or abroad, or from public or private research centers.
L'archive ouverte pluridisciplinaire HAL, est destinée au dépôt et à la diffusion de documents scientifiques de niveau recherche, publiés ou non, émanant des établissements d'enseignement et de recherche français ou étrangers, des laboratoires publics ou privés. 


\section{Karst-river interaction, elaboration of an indicator of the karst hydrological conditions applied to the Cèze River (Gard, France)}

Hervé Chapuis, University of Lyon, UMR EVS 5600, Department Process for Environment and Georesouces, Saint-Etienne School of Mines, 158 Cours Fauriel - CS 62362, F-42023, Saint-Etienne, France, mail : h.chapuis@anteagroup.com, phone : +33672117274

Jordan Ré-Bahuaud, University of Lyon, UMR EVS 5600, 18 rue Chevreul - CS 69362, France, mail : jordan.re-bahuaud@emse.fr

Joël Jolivet, University of Nice-Sophia-Antipolis and CNRS, UMR 7300 ESPACE, France, mail : joel.jolivet2@wanadoo.fr

Frédéric Paran, University of Lyon, UMR EVS 5600, Department Process for Environment and Georesouces, Saint-Etienne School of Mines, 158 Cours Fauriel - CS 62362, F-42023, Saint-Etienne, France, mail : paran@emse.fr

Didier Graillot, University of Lyon, UMR EVS 5600, Department Process for Environment and Georesouces, Saint-Etienne School of Mines, 158 Cours Fauriel - CS 62362, F-42023, Saint-Etienne, France, mail : graillot@emse.fr

Keywords: karst, hydrological indicator, spring discharges, Cèze River

\section{Abstract}

In the interest of creating a point of reference allowing to know the hydrological conditions of the karst system and for the purpose of using it as a parameter in a modelling procedure, a Hydric Indicator of the Karst (HIK) was established from the knowledge acquired on the functioning of the karstic hydrosystem of the Cèze. This indicator makes it possible to identify and qualify if at a specific moment "t" the karst is more able to contribute to the flow of the river or on the contrary to infiltrate precipitation water.

The HIK is constructed from the data collected at the Ussel spring and the MétéoFrance rain gauge at the karst plateau of Méjannes-le-Clap (Gard, France). Chronic rainfall and discharge measurements from the source include two hydrological cycles. The discharge of the spring is calculated from the recordings of water amounts from autonomous water level probes. These water levels are converted into discharge through a calibration curve drawn for this study. For rain events with at least $4 \mathrm{~mm}$ of precipitation, ten parameters on rainfall characteristics and the flow rate of the Ussel spring are analyzed to obtain the HIK. In total, 74 events were analyzed.

Finally, this indicator is a relevant entry for the simulation of flow variations in the river within its karst canyon. It is also a relevant tool for institutions which monitor the condition of the karst aquifer and thus can be a useful tool for the management of the aquifer. Our goal was to develop an approach, with which we can calculate and predict, what will be the response at karst spring, if we know current discharge of the Ussel spring and expected amount of rainfall. 


\section{Introduction}

Karst aquifer studies arouse a great interest given the fact that they represent important freshwater resources. According to (Ford and Williams, 1989 / 2007), the karst rocks cover 7-10\% of the Earth's surface and supply drinking water to about $25 \%$ of the world's population and most of studies mention larger areas underlain by carbonate rocks from $15 \%$ to $20 \%$ (WoKAM 2017, White 1988, Ford \& Williams 2007). Karst systems are characterized by the underground flows (Bakalowicz, 2005). In order to understand the underground flows, many models integrate data of karst system (Kiraly, 1998; Jourde et al., 2007; Johannet, 2011; Fleury et al., 2011; Bailly-Comte et al., 2010 and Bailly-Comte et al., 2012) but this work focuses to elaborate an indicator which represents the hydrological condition of the karst. The results of this work can give perspectives for future modelling of the karst system.

The interactions between the karst system and the river, in terms of flow quantities, vary during a hydrological cycle. Identification of responses of karst aquifers is very important to protect people from flooding and for sustainable development of groundwater management.

\section{Hydrogeological context of the studied area}

Located in a large karstic area in the South of France between the Ardèche and the Cèze Rivers, both tributaries of the Rhône River (Fig. 1), the study area is the subject of a multidisciplinary study which aims to characterize exchanges between aquifer and Cèze river (Ré-Bahuaud et al., 2015). This study area is an attempt to meet a territorial policy, in order to obtain a sustainable management of streams and aquifers. In this location, the Mediterranean climate induces a period of drought in summer and high-flood in autumn. The karst area is a calcareous plateau incised by the Cèze River. Sometimes during drought period the Cèze River may dry up and the water from the river infiltrates into the calcareous aquifer (Chapuis, 2017). This calcareous plateau is geologically and hydrogeologically well studied, including by borehole investigations, karstic network investigations and especially previous groundwater tracing (Jolivet, 2013 and Pouzancre, 1971). The size of the recharge area is about $200 \mathrm{~km} 2$, amount of the outflow can be estimated to $2 \mathrm{~m}^{3} / \mathrm{s}$ for the minima flow during dry period and can rise to $200 \mathrm{~m}^{3} / \mathrm{s}$ in winter so that, average is not relevant. Highest discharge of studied springs are about $2 \mathrm{~m} 3 / \mathrm{s}$ (Maranade spring). Geological studies suggest interactions between river and Lower Cretaceous formations, Barremian and Lower Aptian (so called Urgonian) formations which is a highly karstified calcareous geological unit. Whether on the Cèze right bank, some springs may dry up during drought period. The interactions between the karst system and the river, in terms of flow quantities, vary during a hydrologic cycle. In this karst system, water sinking is caused by contacts between specific formations and fault thrust zones.

\section{Hydrological indicator of the karst}

The construction of the approach is based on the observation of the different parameters recorded at karst springs and rainfall events, for settings that might range from exhausted to saturated. Following the design of this indicator, the aim of the study is the construction of the model with the help of this hydrological indicator. The information about the water balance in karst aquifer can then be used for anticipating the accentuated or attenuated shape of a river or spring hydrograph after a rainfall event.

Though many data may be available, for a simplified and manageable job it is imperative to have a welladapted time step. Representative data set of the karst hydrosystem is required to design a reliable model. For this reason, the Ussel spring data were selected, as a tracer data showing that they probably represent a large karst basin. Precipitation data from Méjannes-le-Clap Plateau also represent as well as the Méjannes-le-Clap precipitation data from MeteoFrance that represent an uninterrupted longterm data set.

These data were subjected to an event-related analysis. In fact, within these two time-related data sets, we analyzed the hydrological response of the spring for a rainfall event with at least $4 \mathrm{~mm}$ of precipitation. Selection of such intensive rainfall events enables identification of event that affects spring discharge. If the analysis comprises events of such a weak intensity it is to clearly mark the distinction 
between rainfall events that affect spring flow, and those that are too weak and thus are buffered by the karst network and also capped by evapo-transpiration. Depending on initial conditions, rain events which have less than $4 \mathrm{~mm}$ of precipitation have no influence on springs discharge and are not significant since there are buffered by the karst network. Such rainfall and flow-rate data provide several parameters for each event:

- volume of precipitated water (in $\mathrm{mm}$ ),

- intensity of precipitation ( $\mathrm{mm}$ per $1 \mathrm{~h}, 2 \mathrm{~h}, 5 \mathrm{~h}$ and per $10 \mathrm{~h}$ ),

- maximum intensity of precipitation,

- centre of gravity of the rainfall hydrograph (in $\mathrm{mm} / \mathrm{h}$ ),

- cumulative rainfall several days before a remarkable rainfall event ( $\mathrm{mm}$ in $3 \mathrm{~d}, 15 \mathrm{~d}$ and $30 \mathrm{~d}$ ),

- initial stage at the spring (in L/s),

- total water volume transiting through the spring during one high water event,

- total water volume transiting through the spring during one high water event less base volume $\left(\mathrm{m}^{3}\right)$,

- centre of gravity of the spring hydrograph $\left(\mathrm{m}^{3}\right)$

- maximum flow rate transiting through the spring $\left(\mathrm{m}^{3} / \mathrm{s}\right)$.

These parameters are obtained by the analysis of the hydrological response at the rainfall events. The flow rate parameter of the Ussel spring result from the stage recorded with an autonomous probe. This database is converted in flow rate thanks to a tare curve.

A total of 74 events have been analyzed from 2013 to 2015 .

HIK is given by the correlation curve of precipitation versus Ussel spring discharge.

\section{Construction of the hydrological indicator}

The hydric conditions of karst system are divided in three ranges corresponding to the colors green, yellow and black in figure 2 .

This study was done using manual iteration (without computer assistance) and comparing the evolution of ten parameters, previously described.

The first range $=$ HIK 1 (hydric indicator of karst) $=$ initial flow rate of Ussel spring is lower than $220 \mathrm{~L} / \mathrm{s}$. The second range (consider as the period of transition between HIK 1 and HIK 3 ) $=$ HIK $2=$ initial flow rate of Ussel spring is ranging from $220 \mathrm{~L} / \mathrm{s}$ to $350 \mathrm{~L} / \mathrm{s}$.

The third range $=\mathrm{HIK} 3=$ initial flow rate of Ussel spring is higher than $350 \mathrm{~L} / \mathrm{s}$ (in high level water period before one rain event).

\section{Results obtained with HIK}

Figure 2 shows the peak flow transiting through Ussel spring (ordinate) in terms of maximum hourly rainfall over the Méjannes-le-Clap plateau (abscissa). The three colorful points on the figure 2, green, yellow and black, are the third variable integrated from all described parameters. This third parameter called "HIK" calculates the karst-system water balance. An example on Figure 2 shows the initial flow rate before the rain event begins. According to spring discharge HIK is divided to three classes and represented with aforementioned colors. From HIK 1 to HIK 3 , this parameter represents a karst network passing from a drying-up stage to a saturated stage. The result shown on figure 2 shows that the Ussel spring behaves differently according to rainfall intensity, as shown by the green, yellow and black points. In fact, HIK 1 represents the group of events, where the maximum flow rate of the spring does not increase strongly, even though the rainfall is strong. Even though the green points follow an exponential curve, only more than $60 \mathrm{~mm}$ of rain in one hour increases the spring flow $\left(1.7 \mathrm{~m}^{3} / \mathrm{s}\right)$, which normally does not exceed $0.5 \mathrm{~m}^{3} / \mathrm{s}$ (current measurements of the Ussel spring discharge should confirm the exponential shape of the curve). Distribution of events, belonging to class HIK 3 (black points) shows a more-or-less linear curve where the maximum flow rate of Ussel spring increases by about $1 \mathrm{~m} 3 / \mathrm{s}$ for an amplification of $10 \mathrm{~mm}$ of precipitation in one hour.

Presented results enable qualitative expression of hydrological conditions of the karst system, and we can design an indicator for the water balance of karst. After construction of the indicator we can predict 
the reaction of the Ussel spring, if its initial discharge and predicted amount of the rain (by MeteoFrance) are known.

\section{Conclusion}

The creation of karst spring database in response to the precipitation events gives many possibilities for interpretation of hydrological conditions of the karst system and its response to rainfall event.

In our case, this database allows to identify the hydrological conditions of studied karst system. This information is important because it's the crucial parameter which determines the groundwater dynamics in the karst system. The proposed methodology can be very useful and applied in further studies or in other karst systems under the same availability of data.

Indeed, hydrological indicator is needed to integrate relevant data into a groundwater model. In that case, this could be possible to use also this approach for other karst systems with well measured water level (discharges) of springs and rain precipitation. This indicator can be integrated in a hydrologic model in order to provide a relevant parameter on the interactions between the karst system and the river. The hydrological indicator of the karst informs the model if the karst system has a less restitution of the infiltrated water (HIK 1) or conversely the karst system is saturated and restitutes the infiltrated water by the karstic springs, see figure 3 .

On this figure 3 (left side), initial hydrological conditions in aquifer given by HIK and spring hydrograph for the same event will be marked.

In the middle and right side: the modelling process which provides river water flows with the contribution of the karst.

After determining the flow rate ranges corresponding to the hydric conditions of the karstic system, this indicator can be a useful tool to determine the hydrological conditions of the hydrosystem and prevent of exploitation risks of the aquifer if there are pumping in low water period.

\section{Acknowledgements}

The authors would like to thank MeteoFrance Company for the precipitation database. Acknowledgement to Ms Leila ESGAIB SÁNCHEZ for her contribution in reviewing the translation of this article. 


\section{References}

Bailly-Comte, V., Borrell-Estupina, V., Jourde, H., Pistre, S., 2012. A conceptual semidistributed model of the Coulazou River as a tool for assessing surface water-karst groundwater interactions during flood in Mediterranean ephemeral rivers. Water Resour. Res. 48, W09534. https://doi.org/10.1029/2010WR010072

Bailly-Comte, V., Martin, J.B., Jourde, H., Screaton, E.J., Pistre, S., Langston, A., 2010. Water exchange and pressure transfer between conduits and matrix and their influence on hydrodynamics of two karst aquifers with sinking streams. Journal of Hydrology 386, 55-66. https://doi.org/10.1016/j.jhydrol.2010.03.005

Bakalowicz, M., 2005. Karst groundwater: a challenge for new resources. Hydrogeol J 13, 148-160. https://doi.org/10.1007/s10040-004-0402-9

Fleury, P., Charlier, J.-B., Borrell, V., Coustau, M., 2011. Appui au SCHAPI 2011 - Module 1: Mise en place d'un indicateur d'aide à la décision pour la prévision de crue en milieu karstique: les bassins versants du Lez et de la Tardoire.

Ford, D.C., Williams, P.W., 1989. Karst geomorphology and hydrology. Academic Division of Unwin Hyman London.

Ford, D.C., Williams, P.W., 2007. Karst geomorphology and hydrology. Academic Division of Unwin Hyman London.

Chapuis H., Jolivet, J., Ré-Bahuaud, J., Paran, F., Graillot, D., Guy, B., 2017. Displacement of Watershed between Two Karstic Rivers. IOP Conference Series: Earth and Environmental Science 95, 022021.

Johannet, A., 2011. Modélisation par apprentissage statistique des systèmes naturels, ou en interaction avec un environnement naturel. Applications aux karsts, crues éclair et en robotique.

Jourde, H., Roesch, A., Guinot, V., Bailly-Comte, V., 2007. Dynamics and contribution of karst groundwater to surface flow during Mediterranean flood. Environ Geol 51, 725-730. https://doi.org/10.1007/s00254-006-0386-y

Kiraly, L., 1998. Modelling karst aquifers by the combined discrete channel and continuum approach. Bulletin d'Hydrogéologie 16, 77-98.

Ré-Bahuaud, J., Jolivet, J., Marmonier, P., Johannet, A., Graillot, D., Paran, F., Chapuis, H., Guy, B., Faroux, J., Creuzé des Châtelliers, M., Olivier, M.-J., Jacquy, M., Lawniczak, M., Novel, M., Savary, M., Salze, D., Vayssade, B., 2015. Caractérisation des échanges entre eaux superficielles (rivière) et eaux souterraines en domaine karstique. Exemple d'un affluent du Rhône, la Cèze (30). Rapport provisoire année 2 (2014-2015) (Action n43 du Programme 2014 (action 49 en 2015) au titre de l'accord cadre Agence de l'Eau ZABR).

White, W. B., 1988. Geomorphology and hydrology of karst terrains. New York: Oxford university press. (Vol. 464).

WoKAM, 2017. World Karst Aquifer Map (WoKAM) 1: 40 000. Published in 2017 and presented at the $44^{\text {th }}$ Congress of the International Association of Hydrogeologists (IAH). Dubrovnik/Croatia. 